\title{
Proposed APSA Constitutional Amendments
}

A PSA has received three petitions to amend the APSA Constitution. One proposal has been submitted by a petition of at least 50 APSA members. The other two proposals have been submitted by the APSA Council.

All three amendments will be placed on the agenda of the APSA All-Member Business Meeting. If an amendment receives the support of $40 \%$ of the present and voting members at the business meeting, the amendment will be placed on the ballot for an all-member vote.

Further information and recommendations from the APSA Council will be posted on APSA website at www.apsanet.org/ amendments2011

The amendments are presented here in the order that they were first received by APSA.

\section{COUNCIL PETITION TO AMEND ARTICLE V (2) OF THE APSA CONSTI- TUTION TO READ:}

2. After each annual meeting the President shall appoint with the advice and consent of the Council and with due regard to geographical distribution, the fields of professional interest, types of institution, race, ethnicity, methodological orientation, sexuality and gender identity, and other important forms of diversity, three members to a Nominating Committee of six, to serve for two-year terms; and he or she shall designate the chair. The Committee may canvass the membership directly or indirectly for suggestions, and shall submit to the next Annual Business Meeting one nomination for each elective office to be filled, except the Presidency. These nominations shall be announced to the membership, by any convenient means, well in advance of the Annual Meeting. Additional nominations, sponsored by at least 10 members of the Association, may be offered from the floor at the Annual Business Meeting, upon 24 hours advance notice to the Secretary.

\section{Article IV: Officers}

1. The officers of the Association shall be a President, a President-Elect, two Vice-Presidents, a Secretary, a Treasurer, and sixteen Members of a Council, who shall represent the Association in its corporate capacity. All officers except the President shall be elected by the membership; the President-Elect will succeed to the presidency automatically one year after his or her election. In addition, there shall be an Executive Director of the Association, a Managing Editor of the American Political Science Review, a Managing Editor of Perspectives on Politics, and such other appointive officers and committees as are hereinafter provided for.

2. The elected officers, together with the Executive Director, the two Managing Editors, and the Chair of the Program Committee, shall constitute the Council of the Association. Ex-Presidents of the Association, and upon invitation of the President, the chair of any committee of the Association and nominees to the next year's Council, may attend meetings of the Council and participate in its discussions but have no vote.

3. The President, the President-Elect, the Treasurer, and four Members of the Council chosen by their Council colleagues shall constitute the Council's Administrative Committee.

\section{Article V: Elected Officers}

1. The elected officers shall be chosen by vote of the members of the Association in an election conducted by ballot of the entire individual membership. The Executive Director shall distribute ballots within thirty (30) days following the Annual Business Meeting and under such other conditions as the Council may prescribe, and he or she shall count only ballots returned within fifteen (15) days following distribution. The outcome of each election shall be determined by a plurality of those voting on the particular office. Association members shall be entitled to cast one vote each for President-Elect, Secretary, and Treasurer, two votes for Vice-President, and eight votes for ordinary Members of the Council. The President-Elect shall succeed to the office of President upon the completion of the President's term, or upon the occurrence of one of the contingencies provided for in section 3 of this article. The terms of the President, President-Elect, Vice-Presidents, and Secretary shall extend for one year measured from the end of the program of the Annual Meeting, except that the term of each shall in no event expire until his or her successor assumes office. The terms of ordinary Members of the Council and the Treasurer shall extend for two years, similarly calculated. The terms of one-half of the Council's sixteen Members shall expire each year.

2. Prior to each annual business meeting, a Nominating Committee of six members shall nominate two candidates for each Council post subject to election. The Committee will nominate two candidates each for President-Elect, Secretary, and Treasurer, four candidates for the two posts of Vice-President, and sixteen candidates for the eight Members to be elected each year on the Council. The Committee shall canvass the Association membership, including the chairs of Organized Sections and affiliated Caucuses, for suggestions, and it shall select candidates with due regard to geographical distribution, fields of professional interest, types of institution, race, ethnicity, methodological orientation, sexuality and gender identity, and other important forms of diversity. The committee's nominations and the candidates' position statements shall be announced to the membership, by any convenient means, well in advance of the Annual Meeting. Additional nominations, sponsored by at least twenty members of the Association, may be offered from the floor at the Annual Business Meeting, upon twenty-four hours advance notice to the Secretary.

The members of the Nominating Committee shall themselves be elected by a ballot of the entire individual membership of 
the Association in an election held simultaneously and in the same form as that of the Council. The Administrative Committee of the Council, with the consent of the full Council, shall nominate two candidates for each post to be filled on the Nominating Committee, applying the same criteria for diversity that are listed in the previous paragraph. Members of the Nominating Committee shall serve two-year terms, half of which shall expire each year. The President shall designate the chair of the Nominating Committee.

The first 50 signatures are listed in the sequence originally presented:

1. Susan Burgess

2. Andrew Ross

3. Dvora Yanow

4. Brian Caterino

5. Ian Shapiro

6. Patrick Thaddeus Jackson

7. James C. Scott

8. Catherine Zuckert

9. Susan McWilliams

10. James Johnson

11. Tristan James Mabry

12. Lloyd Rudolph

13. Ido Oren

14. Mark Teel

15. Dina Spechler

16. Stephen E. Hanson

17. Laura Katz Olson

18. Thomas Dumm

19. Rogers M. Smith

20. Judith Grant

21. Robert W. Glover

22. Manfred B Steger

23. Beverly Ann Gaddy

24. Terrell Carver

25. Sheila Collins

26. Timothy W. Luke

27. Carlton Larsen

28. Brandon Kendhammer

29. Richard J. Meagher

30. Bruce E. Wright

31. Leonard Williams

32. John Berg

33. Cynthia Burack

34. Stephen Pimpare

35. Stephen Bronner

36. John Enrenberg

37. Samer Shehata

38. Joel Olson

39. Jill Locke

40. Anna R. Kirkland

41. Paisley Currah

42. John Mearsheimer

43. William Scheuerman

44. Kevin Bruyneel
45. Peter Brusoe

46. Leila Kawar

47. Jodi Dean

48. Nandini Deo

49. Morris Bidjerano

50. Kathy Ferguson

COUNCIL PETITION TO AMEND

ARTICLES IV (1-3) AND V (1-2) OF THE APSA CONSTITUTION TO READ:

\section{Article IV: Officers}

1. The officers of the Association shall be a President, a President-Elect, two VicePresidents, a Treasurer, and up to twenty members of a Council, all of whom shall represent the Association in its corporate capacity. In addition, there shall be an Executive Director of the Association, a Managing Editor of the American Political Science Review, a Managing Editor of Perspectives on Politics, and a Chair of the Program Committee and such other appointive officers and committees as are hereinafter provided for.

2. The officers, together with the Executive Director, the Managing Editors, and the Chair of the Program Committee, shall constitute the Council of the Association. Ex-Presidents of the Association, and upon invitation of the President, the chair of any committee of the Association and nominees to the next year's Council, may attend meetings of the Council and participate in its discussions but have no vote.

3. The President, the President-Elect, the Treasurer, and four other officers from the Council appointed by the President with the advice and consent of the Council shall constitute the Administrative Committee of the Council.

\section{Article V: Selection of Officers}

1. The President-elect, two Vice-Presidents, Treasurer and sixteen members of the Council shall be chosen by vote of the members of the Association. Elections shall be conducted by ballot of the entire individual membership. The Executive Director shall distribute ballots within thirty (30) days following the Annual Business Meeting and under such other conditions as the Council may prescribe, and he or she shall count only ballots returned within fifteen (15) days following distribution. Each contested election, except as specified below for the President-Elect, shall be determined by a plurality of those voting on the particular office. When the number of nominees for any elective office exceeds the number of offices constitutionally to be filled, all such nominees shall appear on a ballot. The number of Council seats to be filled at any election is eight. In addition, one President-Elect and one Vice President, shall be elected annually; and one Treasurer shall be elected every two years

2. Members shall be entitled to vote for a number equal to the number of offices in the set. The nominees ranking highest in the poll, in a number equal to the number of offices, shall be declared elected. The President-Elect shall be chosen by the above method only if there are two and only two nominees for the office. Should there be three or more nominees for President-Elect, ballots for that office shall be so designed as to enable members to designate their rank-ordered preferences by placing numbers beside the names of the nominees ("1" for first preference, " 2 " for second preference, and so on for each nominee). If no nominee receives at least fiftypercent-plus-one of the first preferences, other preferences shall be added from the first-preference ballots of each eliminated nominee according to the standard method of the alternative vote system, which shall be prescribed by the Council in advance of nominations, until one nominee receives at least fifty-percent-plus-one of the aggregated preferences and is declared the winner.

3. The President-Elect shall automatically succeed to the office of President upon the completion of the President's term, or upon the occurrence of one of the contingencies provided for in section 7 of this article. The term of the President shall extend for one electoral cycle, and the terms of members of the Council, Vice President, and Treasurer shall extend for two electoral cycles, except that an officer's term shall in no event expire until his or her successor assumes office. An electoral cycle shall begin annually on November 1.

4. The Council shall choose a Secretary from among the members of the Council. Approval of a majority of the Council is required to seat the Secretary. The Secretary serves for a term of one electoral cycle. A sitting Secretary will retain her or his position until her or his replacement is elected, and after stepping down completes her or his term on the Council if it is still current. 
5. Within 6o to 9o days of being elected, the president will propose two additional members to be added to the APSA Council with the advice and consent of the Council. The President shall select candidates with due regard to geographical distribution, fields of professional interest, types of institution, race, gender, ethnicity, methodological orientation, gender, sexuality, and other important forms of diversity. All such nominees must meet the normal requirements of APSA Council nominees. Upon such a recommendation, the approval of $60 \%$ of the Council is required for any such proposal to pass. No more than two Council members can be added in this manner in any electoral cycle, and their terms shall extend for two electoral cycles beginning with the one in which they are selected.

6. Within 9o days of being elected, three members of a Nominating Committee shall be selected annually from newly elected members of the Council for a two year term. The members shall be chosen by lot, following procedures established by the Council and specified in the by-laws. After Nominating Committee membership is determined as described above, the President will name a chair from the members of the Nominating Committee.

The Nominating Committee may canvass the membership directly or indirectly for suggestions, and shall submit to the next Annual Business Meeting one and one half nominations for each elective Council seat and one nomination each for President-elect, Vice President, and, in appropriate years, Treasurer. The Nominating Committee shall select candidates with due regard to geographical distribution, fields of professional interest, types of institution, race, gender, ethnicity, methodological orientation, gender, sexuality, and other important forms of diversity. These nominations shall be announced to the membership, by any convenient means, well in advance of the Annual Meeting. Nominations, sponsored by at least 10 members of the Association, may come from the membership at any time prior to a date established by the Council and specified in the by-laws.

\section{THE CONSTITUTION OF THE AMERICAN POLITICAL SCIENCE ASSOCIATION}

\section{ARTICLE I: NAME}

This Association shall be known as The American Political Science Association.

\section{ARTICLE II: PURPOSE}

1. It shall be the purpose of this association to encourage the study of Political Science, including Political Theory, Political Institutions, Politics, Public Law, Public Administration, and International Relations.

2. The Association as such is nonpartisan. It will not support political parties or candidates. It will not commit its members on questions of public policy nor take positions not immediately concerned with its direct purpose as stated above. But the Association nonetheless actively encourages in its membership and its journals, research in and concern for significant contemporary political and social problems and policies, however controversial and subject to partisan discourse in the community at large these may be. The Association shall not be barred from adopting resolutions or taking such other action as it deems appropriate in support of academic freedom and of freedom of expression by and within the Association, the political science profession, and the university, when in its judgment such freedom has been clearly and seriously violated or is clearly and seriously threatened.

\section{ARTICLE III: MEMBERSHIP}

1. Annual Members. Any person sharing the objects of this Association may become a member upon payment of annual dues. All classes of dues, including life membership and reduced annual dues for retired members and students shall be set by the Council.

2. Life Members. Any person paying dues of a life member in a lump sum, or in installments spread over not more than ten years, shall become a Life Member of this Association and thereafter be exempt from further dues.

3. Student Members. Any graduate or undergraduate student registered in a college or university may become a Student Member of the Association upon payment of dues and may remain such while he or she is so registered, but for no more than five years, by paying annual dues.

4. Family Members. Another person in the family of a member may become a Family Member upon payment of dues, and may remain such as long as there is another Association member in the family, by paying annual dues.

5. Retired Members. Any member who has been a member for twenty-five years prior to retirement shall be entitled, on retirement, to continue membership at the retired members dues rate.

6. Institutional and Library Memberships.
The dues and privileges of Institutional and Library Members shall be fixed by the Council but dues may not be less than those for Annual Members.

7. Privileges of Members. Each member, other than a Family Member, shall be entitled to a copy of each number of the American Political Science Review issued during his or her membership. All members, upon payment of such registration fee as the Council may approve, shall be entitled to attend and to participate in the Annual Business Meeting of the Association.

\section{ARTICLE IV: OFFICERS}

1. The officers of the Association shall be a President, a President-Elect, three VicePresidents, a Secretary, a Treasurer, and sixteen elected members of a Council, all of whom shall be elective officers and who shall represent the Association in its corporate capacity. In addition, there shall be an Executive Director of the Association, a Managing Editor of the American Political Science Review and such other appointive officers and committees as are hereinafter provided for.

2. The elective officers, together with the Executive Director, the Managing Editor, and the Chair of the Program Committee, shall constitute the Council of the Association. Ex-Presidents of the Association, and 